\title{
Prevalence of E. coli O157:H7 in Dairy Cattle and the Farm Environment in the Marmara Region of Turkey ${ }^{[*]}$
}

\author{
Esin BİRDAL ${ }^{*}$ Seyyal AK ${ }^{2}$ \\ ${ }^{\prime}$ Ministry of Food, Agriculture and Livestock, İstanbul Province Directorate, Erenkoy, İstanbul, Turkey. \\ ${ }^{2}$ Department of Microbiology, Faculty of Veterinary Medicine, Istanbul University, Avcllar, İstanbul, Turkey
}

\begin{abstract}
In this study; identification and determination of seasonal prevalence of E. coli O157:H7 from feces and milk in the healthy dairy cattle that were different age groups, and other animals' feces (dog, cat etc.) which were present in the farms. Also environmental samples (barn, calf shelter, paddock, open space, parlor floor, milk tank, calf pads, feed bunk, tractor wheels, a lounge, a nursery, parlor door, barn door, milking parlor door, a nursery wall, cows, ducks and geese drinking water, trough, watering, milk jug, milking machine head, dog kennel, milk cooling tanks, vacuum machine, foot pool, calf bottle, scan, brush, straw bales, shovel and cat, dog paw, dog, lamb and calf feces) of the farms which are public or private establishments, in the Marmara Region of Turkey were included. In this research, 96 fecal and milk samples from the same animals (except death and slaughtering) and 96 environmental samples were collected from the determined 10 farms, in fall and spring periods. Total of 576 (288 samples in the fall period and 288 samples in the spring) samples were examined. The samples were collected totally from 139 animals because of the new animals were added due to death or slaughtering in the spring period. All samples were enriched in modified Tryptic Soya Broth. After the immunomagnetic separation, O157 Dynabeads and bacterial suspensions were inoculated onto sorbitol MacConkey agar with cefixime and tellurite. Sorbitol negative colonies were inoculated onto sorbitol MacConkey agar supplemented with 4methylumbelliferyl- $\beta$-D-glucuronide. Suspected colonies which were chosen from this medium were applied for latex and tube agglutination assays for characterization of $\mathrm{O} 157$ serogroup, biochemical tests and tube agglutination assay for detecting $\mathrm{H} 7$ antigen respectively. In the fall period, E. coli O157 was isolated from one environmental sample and one fecal sample. In the spring period, E. coli O157 was isolated from 10 and E. coli one fecal sample. Seven E. coli O157 isolates were collected from the same farm which tested negative during in the first sampling. In total, 576 samples were examined and two samples were identified as E. coli O157:H7 (0.35\%) and confirmed by PCR assay applied on the BAX System Q7. E. coli O157:H7 was identified in the fall period while didn't isolate in the spring period. Seasonal effect was detected significant only in the isolation rate of $E$. coli $O 157$ in feces $(p<0.01)$.
\end{abstract}

Keywords: Escherichia coli O157:H7, Feces, Milk, Environment, Cattle

${ }^{[*}$ This article was summarized from the first author's PhD thesis.

\section{Marmara Bölgesi’ndeki süt işletmelerindeki ineklerde ve çevrede E. coli 0157:H7 varlığının saptanması}

Öz: Bu çalışmada, Marmara Bölgesinde kamu ve özel sektöre ait süt işletmelerinde bulunan çeşitli yaş gruplarındaki sağllkl ineklerin dışkl ve sütlerinde, çiftlikte bulunan diğer hayvanların (köpek, kedi vs) dışkllarında ayrıca işletmelere ait çevresel örneklerde E. coli O157:H7'nin varlı̆̆ının saptanması, mevsimsel olarak prevalansının belirlenmesi amaçlandı. Bu amaçla belirlenen 10 süt sı̆̆ırcılĭ̆ işletmesinden sonbahar ve ilkbahar dönemlerinde ayn hayvanlardan (ölüm ve kesim dişında) ve çevresel örneklerden tesadüfï örnekleme ile 96 'şar adet dişkl, süt ve çevre örneği toplandl. Birinci dönem 288, ikinci dönem 288 olmak üzere toplam olarak 576 örnek incelendi. Her iki dönemde ölüm ve kesim nedeniyle çalışmaya yeni dâhil edilen inekler ile toplamda 139 ineğe ait örnek incelendi. Örnekler Modifiye Triptic Soy Buyyon'da zenginleştirildi. Immunomanyetik Seperasyon ve ardindan O157 Dynabead ve bakteri kompleksi içeren örneklerden sefiksim ve tellurit ilave edilen Sorbitollü MacConkey agara ekim yapldd. Sorbitol negatif koloniler yeniden 4-methylumbelliferyl- $\beta$-D-glucuronide Sorbitollu MacConkey agara ekildi. Bu besiyerlerinde üreyen şüpheli koloniler seçildi ve bunlara sırastyla O157 serogrubunun tanımlanması için tüp ve lateks aglütinasyon testleri, biyokimyasal testler ve H7 antijenlerinin saptanması için tüp aglütinasyon testi uygulandı. Sonuç olarak, sonbahar döneminde toplanan 288 örnekten çevresel kaynakl bir örnekte E. coli O157, dişkı kaynaklı bir örnekte E. coli O157:H7 izole ve identifiye edildi. İlkbahar döneminde toplanan 288 örneğin dişkı kökenli 10'unda E. coli O157 ve dlşkı kökenli birinde E. coli O157:H7 izole ve identifiye edildi. E. coli O157 identifiye edilen örneklerin 7 'si aynı çiftliğe ait, ilk örneklemede negatif olarak bulunan ineklerdi. Toplam olarak incelenen 576 örneğin iki (\%0.35)'sinde E. coli O157:H7 izole ve identifiye edildi. Sonbahar döneminde E. coli O157:H7 identifiye edilen dişkıdan, ilkbahar döneminde E. coli O157:H7 izole edilmedi. İlkbahar döneminde dişkısından O157:H7 identifiye edilen hayvan, sonbahar döneminde rastgele seçilen hayvanlar arasında yer almaması nedeniyle örnek alınmayan, ikinci örneklemede kesime giden hayvanların yerine rastgele seçilen yeni hayvanlardan biriydi. Yapılan istatistiksel analizler sonucunda sadece dışkıda mevsimsel olarak O157 izolasyon oranı önemli bulundu $(p<0.01)$.

Anahtar sözcükler: Escherichia coli O157:H7, D1șk1, Süt, Cevre, İnek

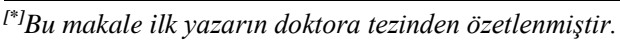




\section{INTRODUCTION}

Escherichia coli is in the Enterobacteriaceae family considered as a submember of the coliform and the fecal coliform groups, and important microorganism of the Escherichia genus (Flemming and Strockbine, 2005). E. coli is Gram negative, catalase positive, oxidase negative, motile, facultative anaerob bacteria and exists in the natural gut flora of human and most of the warm-blooded animals (Gonul, 1997; Cebiroglu, 1998). E. coli has more than 170 serogroups. Within each serogroup, there are one or more serotypes. The numbers which are assigned according to the molecules on bacterial surface indicate a spesific E. coli serogroup and/or serotypes (Peacocket al., 2001).

E. coli strains that cause diarrhea were divided five groups according to infection and serological differences. These groups are; enteropathogenic E. coli (EPEC), enterotoxigenic E. coli (ETEC), enteroinvasive E. coli (EIEC), entero-aggregative E. coli (EAggEC) and enterohaemorrhagic E. coli (EHEC) (Unluturk and Turantas, 1998). Also some researchers include Shiga-toxigenic E. coli in these groups (Franzolin et al., 2005).

EHEC strains, which cause infections such as hemorrhagic colitis, hemolytic uremic syndrome (HUS) and thrombotic thrombocytopenic purpura, are considered as important pathogens for human (Cebiroglu, 1998). Occurrence of complications such as hemorrhagic cystitis, convulsions, sepsis and anemia has been reported in E. coli O157:H7 infected people (Padhye and Doyle, 1992).

It has been reported that, cattle are the main reservoir for E. coli O157:H7 (Dunn, 2003; Caprioli et al., 2005). It has been determined concerning cattle that $E$. coli O157:H7 can colonize in the intestines without causing infection but lead to contamination of meat in slaughterhouses (Elder et al., 2000). Numerous studies have been conducted in order to reveal the prevalence of $E$. coli O157:H7 among animals in Turkey (Cabalar et al., 2001; Kuyucuoğlu et al., 2011; Aslantas et at., 2006; Aydın et al., 2010; Oksuz et al., 2004) and in the world (Zhao et al., 1995; Faith et al., 1996, Mechie et al., 1997; Hancock et al., 1998; Lahti et al., 2003, Schouten et al., 2005). E. coli O157:H7 can be transmitted to people by the consumption of undercooked cattle beef and raw milk and milk products, by the use of contaminated water resources may lead to outbreaks (Cebiroglu, 1998). Also, transmission was possible due to consumption of fruits and vegetables contaminated with feces (Caprioli et al., 2005). Presence of E. coli $\mathrm{O} 157: \mathrm{H} 7$ in meat and meat products as well as milk and dairy products is determined with numerous studies (Akkaya et al.,2007; Unsal, 2007). In addition, E. coli O157: H7 was detected in venison (Keene et al., 1997) and seafood products, apple cider (Beser et al., 1993). Hancock et al. [Hancock et al., 1998], have reported in their conducted study in 12 cattle farms in the United States, E. coli 0157 prevalence were between $1.1 \%$ and $6.1 \%$ in the feces of cattle, while $1.1-3.1 \%$, in other animals present in the farms. Also isolation rates from the flies and water containers were $3.1 \%$ and $3.3 \%$ respectively. Lahti et al. (Lahti et al., 2003) have reported in their study that they detected E. coli $\mathrm{O} 157$ in 110 out of 688 fecal samples (16\%), $18(24.3 \%)$ out of 74 water troughs and $24(36.9 \%)$ out of 65 feed bunk in a farm in Finland.

It has been emphasized that the amount of $E$. coli O157:H7 which is part of a gut microflora of cattle varies according to their ages (Cicek, 2008). Furthermore, some studies have shown that there was an increase in the amount of E. coli O157: H7 during the summer season (Cicek, 2008; Dunn, 2003; Franzolin et al., 2005).

The aim of this study was to investigate the seasonal prevalence of E. coli O157:H7 from dairy cattle (feces, milk), the other animals (dog, cat etc.) present in the farms and the environment of the dairy farms in Marmara Region of Turkey.

\section{MATERIALS AND METHODS}

Samples: In our study, samples of feces, milk from cattle and environmental samples from the establishments have been examined. For the research, 10 dairy farms have been selected from various cities in the Marmara Region. Sample collection has been performed twice with six months intervals during fall (November) and spring period (May) in the same animals (except the addition of new animals due to death and slaughtering). In the second sampling 53 of the dairy cattle were the same as in the first sampling whereas 43 dairy cattle were different.

Since the prevalence of $E$. coli $0157: \mathrm{H} 7$ was unknown, 96 per fecal, milk and environmental samples have been collected. Fecal and milk samples have been collected from each dairy cattle. Also environmental samples such as barn, calf shelter, paddock, open space, parlor floor, milk tank, calf pads, feed bunk, tractor wheels, a lounge, a nursery, parlor door, barn door, milking parlor door, a nursery wall, cows, ducks and geese drinking water, trough, watering, milk jug, milking machine head, dog kennel, milk cooling tanks, vacuum machine, foot pool, calf bottle, scan, brush, straw bales, shovel and cat, dog paw, dog, lamb and calf feces were collected.

Fecal samples of cattle were collected by rectal palpation and stored in sterile stool container. Milk samples were collected during the morning or evening milking and stored into sterile tubes. Fecal samples of other animals and environmental samples were collected with sterile swabs and inoculated into $10 \mathrm{ml}$ PBS. 
All samples were taken to the laboratory of Istanbul University, Veterinary Faculty, Department of Microbiology under cold chain conditions within six hours.

Isolation and identification: Portions of approximately $1 \mathrm{~g}$ of fecal, $1 \mathrm{ml}$ of milk samples were collected and taken to the laboratuary into PBS. Environmental and fecal samples of other animals were mixed, $1 \mathrm{ml}$ of each sample were taken and inoculated into mTSB (Oxoid CM0129) and incubated under aerobic conditions for $8 \mathrm{~h}$ at $37^{\circ} \mathrm{C}$ (Schouten, 20059. After incubation immunomagnetic separation with dynabeads anti E. coli $\mathrm{O} 157$ beads (Invitrogen 710.04) was performed (Bayar, 2007).

Immunomagnetic separation beads were plated onto sorbitol MacConkey agar (Difco 279100) plates containing cefixime $(50 \mu \mathrm{g} / \mathrm{L})$ and tellurite $(2.5 \quad \mathrm{mg} / \mathrm{L})$ (Oxoid SR0172E) (CT-SMAC). Plates were incubated for $20 \mathrm{~h}$ at $37^{\circ} \mathrm{C}$ and examined for the presence of sorbitol-negative colonies. Sorbitol-negative colonies were inoculated onto SMAC supplemented with $0.1 \mathrm{~g}$ 4-methylumbeliferyl-betaD-glucuronide (MUG; Oxoid BR0071E) and incubated for $20 \mathrm{~h}$ at $37^{\circ} \mathrm{C}$ (Schouten, 2005). Sorbitol-negative and MUGnegative colonies were tested for agglutination by the $E$. coli O157 latex (Oxoid DR I20M) (Bayar, 2007) and tube agglutination assays as described by the manufacturer (BD Difco 2207901). The bacteria were found positive by the agglutination assay were confirmed as $E$. coli by conventional biochemical tests. E. coli $\mathrm{O} 157$ isolates were tested by tube agglutination (BD Difco 221591) for the presence of the $\mathrm{H} 7$ antigen by using antiserum as described by the manufacturer. The isolates were confirmed by PCR assay applied on the BAX System Q7 (Dupont, Qualicon, Wilmington, USA).

In order to determine the statistical importance of age and season "Khi-Kare" $\left(\mathrm{X}^{2}\right)$ test were used (Ozdamar, 1999).

\section{RESULTS}

First sampling (fall period) results: Result of the first sampling (fall period), E. coli $\mathrm{O} 157$ was identified from one environmental sample (ducks and geese pool water), $E$. coli O157:H7 was identified from one fecal sample out of 288 samples (Table 1).
Second sampling (spring period) results: Result of the second sampling (spring period), all of the E. coli 0157 and $E$. coli $\mathrm{O} 157: \mathrm{H} 7$ identifications were obtained from the cattle feces.

Out of 288 samples collected in the second sampling period, ten of the isolates were identified as $E$. coli O157, one of them as E. coli O157:H7 (Table 1). Seven of the samples that $E$. coli was identified belonged to the animals from the same farm and tested as negative in the first sampling. E. coli $\mathrm{O} 157: \mathrm{H} 7$ has not been identified from the cattle that $E$. coli $\mathrm{O} 157: \mathrm{H} 7$ has been identified in the first sampling and the other samples belonged to this farm.

Table 1. Identification results of E. coli $\mathrm{O} 157$ and E. coli O157:H7 in the fall and the spring periods.

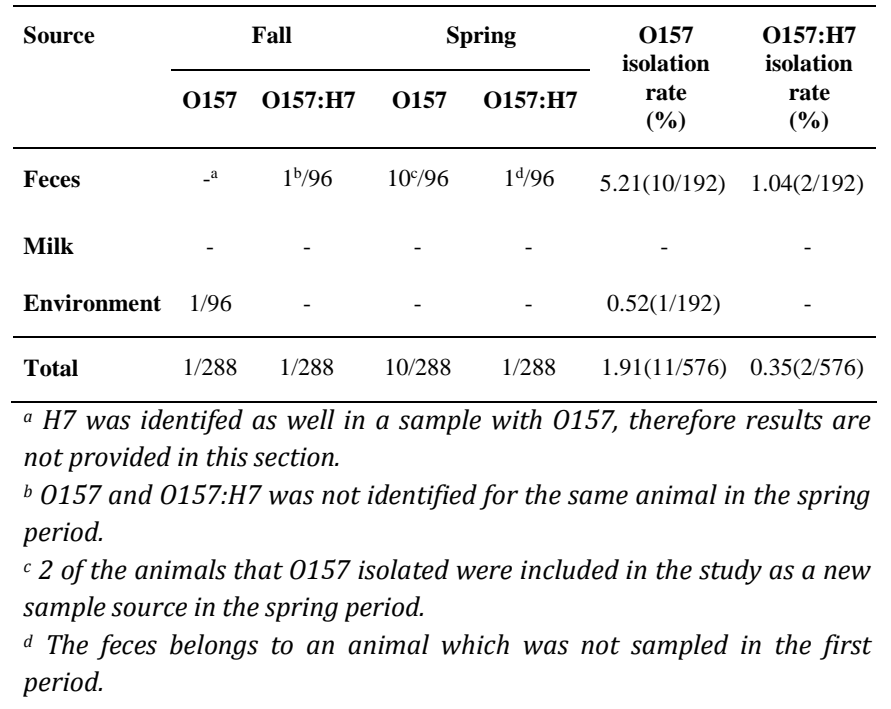

The cattle that identified as E. coli $\mathrm{O} 157: \mathrm{H} 7$ in the second sampling was a new animal which was added because of slaughtering. Therefore, this animal had not been examined during the first sampling.

Results of statistical analysis: Seasonally $\mathrm{O} 157$ isolation rates in feces have been found statistically significant $(\mathrm{p}<0.01)$ (Table 2$)$. Isolation rates by age have not been found significant (Table 3 ).

Table 2. Isolation rates of E.coli $\mathrm{O} 157$ and $\mathrm{O} 157: \mathrm{H} 7$ according to seasons ${ }^{\mathrm{a}}$

\begin{tabular}{|c|c|c|c|c|c|c|c|c|}
\hline \multirow[t]{3}{*}{ Source } & \multicolumn{4}{|c|}{ Fall (November) } & \multicolumn{4}{|c|}{ Spring (May) } \\
\hline & \multicolumn{2}{|l|}{ O157 } & \multicolumn{2}{|c|}{ O157:H7 } & \multicolumn{2}{|c|}{ O157 } & \multicolumn{2}{|c|}{ O157:H7 } \\
\hline & Identification & $\%$ & Identification & $\%$ & Identification & $\%$ & Identification & $\%$ \\
\hline Feces & - & 0 & $1 / 96$ & 1,04 & $10 / 96$ & 10.42 & $1 / 96$ & 1,04 \\
\hline Environment & $1 / 96$ & 1.04 & - & 0 & - & 0 & - & 0 \\
\hline
\end{tabular}

${ }^{a}$ Seasonally $\mathrm{O} 157$ isolation rates in feces have been found statistically significant $(p<0.01)$. 
Table 3: Isolation rates of E. coli $\mathrm{O} 157$ and $\mathrm{O} 157: \mathrm{H} 7$ according to age $(n=139)$.

\begin{tabular}{ccccc}
\hline Age & \multicolumn{2}{c}{ O157 } & \multicolumn{2}{c}{ O157:H7 } \\
\cline { 2 - 5 } year) & İdendification & $\%$ & İdendification & $\%$ \\
\hline $\mathbf{1 - 3}$ & - & 0 & - & 0 \\
$\mathbf{3 - 6}$ & 7 & 5.03 & 2 & 1.44 \\
$\mathbf{6 - 1 0}$ & 3 & 2.16 & - & 0 \\
\hline
\end{tabular}

\section{DISCUSSION}

Cattle are considered as the primary reservoir of $E$. coli O157:H7 (Caprioli et al., 2005; Dunn, 2003; Zhao et al., 1995). E. coli O157:H7 prevalence was detected $1-5 \%$ in the United States (Zhao et al., 1995), 1-15.7 \% in several European countries (Cahpman et al., 1997) from cattle fecal samples. E. coli $\mathrm{O} 157: \mathrm{H} 7$ has been isolated from $1.4 \%$ of 1266 milk samples taken from healthy dairy cattle in the United States (Wells et al., 1991), from $0.7 \%$ of 144 raw milk samples belonging to cattle and goats in Italy (Unluturk and Turantas, 1998). Heuvelink et al. (1998) has not isolated E. coli $\mathrm{O} 157$ from any of the 1011 raw milk samples in the Netherlands.

E. coli $\mathrm{O} 157: \mathrm{H} 7$ was detected in $1.28 \%$ of 312 fecal samples from healthy dairy cattle in the Van province (Eastern part) of Turkey (Cabalar et al., 2001) and in $1.3 \%$ from feces and milk of the cattle in the Aegean region (Western part) of Turkey (Cicek, 2008). Gonul (Gonul, 1997), has reported that E. coli O157: H7 was isolated from 1 of 30 tulum cheese cans, moreover E. coli 0157:H7 was not isolated from 20 raw milk samples. Aydın et al. (2010) have isolated E. coli $\mathrm{O} 157$ from 1 of 500 milk samples $(0.2$ $\%$ ) and 6 of 500 fecal samples (1.2\%), but did not detected $\mathrm{H} 7$ antigen in any of the samples. Kuyucuoglu et al. (2011), have reported E. coli $\mathrm{O} 157: \mathrm{H} 7$ from 14 of 457 fecal samples (237 calf and 220 cattle). Oksuz et al. (2004), have detected E. coli $\mathrm{O} 157$ in $1 \%$ of the 100 raw milk samples.

In this study, 96 milk and 96 fecal samples were collected in the spring and fall periods in dairy cattle farms. In total, 139 fecal samples were examined. E. coli O157:H7 was isolated in two $(1.04 \%)$ of fecal samples $(n=192)$. The animal which E. coli $\mathrm{O} 157: \mathrm{H} 7$ was isolated from fecal sample in the fall period, was not isolated in the spring period. This result made us thought that the animal was not in the shedding period. However, there was no increase in the prevelance of E. coli $\mathrm{O} 157: \mathrm{H} 7$ concerning the other animals at the farm. Furthermore, no E. coli O157:H7 was detected from the milk samples belonging to 139 cattle.

Researchers have reported that the environmental elements in contact with dairy cattle, could play a role in spreading of E. coli O157: $\mathrm{H} 7$ to their surroundings (Lahti et al., 2003; Schouten et al., 2005). It has been pointed that especially water sources could be the reservoir and had an important role in spreading of E. coli O157 (Faith et al., 1996; Hancock et al., 1998; Schouten et al., 2005). Schouten et al. (2005), reported that nine E. coli O157 VTEC were isolated out of 594 environmental samples taken from dairy cattle farms (from one puddle on the farm premises, two on the manure injector, one in the feed bunk and five on the slatted floor). Furthermore, they have taken samples from animals other than cattle and isolated E. coli O157 VTEC from 2 of the 39 swabs taken from two dogs, 1 of 18 fecal samples of the horses and 2 of 12 fecal samples from the chickens in the run. Lahti et al. (2003), have collected samples from water container, floor and feed bunks in their conducted study, as a result E. coli $\mathrm{O} 157$ was isolated from 18 out of 74 water container, 8 out of 10 floor sample and 24 out of 65 feed bunk. In this study, as a result of the first sampling (fall period), E. coli $\mathrm{O} 157$ was identified from one sample taken from ducks and geese pool water.

Several researchers, have isolated E. coli $\mathrm{O} 157: \mathrm{H} 7$ in fecal samples and from the milk taken directly from the animals however, they have not been able to isolate $E$. coli O157:H7 in the milk tanks, milk filters, churns, vacuum machines and milking machine (Mechie et al., 1997).

Moreover, in this study, carriage of E. coli $\mathrm{O} 157$ from feces, milk and environmental samples were identified as $6.25 \%, 0 \%$ and $0.52 \%$ respectively . An important fact to consider regarding our findings is that seven out of ten $\mathrm{O} 157$ strains that were isolated from the feces in the spring period belong to the same farm. Isolation of E. coli $\mathrm{O} 157$ was considered to be a risk factor.

The researchers have emphasized that the particular season of sampling may be important and the fecal shedding of $E$. coli $\mathrm{O} 157: \mathrm{H} 7$ increased especially during the summer months (Caprioli et al., 2005; Dunn, 2003). Aslantas et al. (2006), have reported that E. coli $\mathrm{O} 157$ isolation was higher in July and November, the lowest isolation detected in February. Chapman et al. (1997), have notified that the highest E. coli $\mathrm{O} 157$ isolation rate occurred in July and September. However, Richards et al. (1998), reported that the seasonal effect was not significant.

It has been reported that this pathogen occured more in the feces of calves especially during the postweaning period compared to adults (Caprioli et al., 2005, Dunn, 2003).

Garber et al. (1995), have pointed that weaning had a positive correlation with $E$. coli $\mathrm{O} 157: \mathrm{H} 7$ in shedding the agent. The fecal shedding of E. coli O157:H7 was found to be more in calves and heifers compared to adults (Zhao et al, 1995).

In conclusion, the existence and prevalence of $E$. coli $0157: \mathrm{H} 7$ were detected as $0.35 \%$ of feces and environmental samples in the Marmara Region in sampled dairy farms. 


\section{ACKNOWLEDGMENT}

This study was supported by Istanbul University Research fund (project no. 5204, UDP: 30496/25012013).

\section{REFERENCES}

Akkaya, L., Alişarlı, M., Kara, R. \& Telli, R. (2007). The prevalance of E. coli $\mathrm{O} 157: \mathrm{H} 7$ in raw milks and cheeses sold in Afyonkarahisar Province, Turkey. Journal of the Faculty of Veterinary Medicine University of Yuzuncu Yil, 18(1), 1-5.

Aslantaş, O., Erdoğan, S., Cantekin, Z., Gülaçtı, I. \& Evrendilek, GA. (2006). Isolation and characterization of verocytotoxin-producing Escherichia coli $\mathrm{O} 157$ from Turkish cattle. J. Food Microbiol., 106(3), 338-342.

Aydın, F., İça, T. \& Yontar, A. (2010). Investigation with conventional and molecular method of Escherichia coli in dairy cattle in Kayseri Region. JHS., 19(3), $159-166$

Bayar, S. (2007). Investigation and determination of Escherichia coli 0157:H7 in meat and meat products which sold in Izmir. (Master's Degree Thesis). Ege University, Institute of Science, Izmir, Turkey.

Beser, T.E., Lett, S.M., Weber, J.T., Doyle, M.P., Barrett, T.J., Wells, J.G., Patricia, M. \&Griffin, M.D. (1993). An outbreak of diarrhea and haemolytic uraemic syndrome from Escherichia coli $\mathrm{O} 157: \mathrm{H} 7$ in fresh pressed apple cider. JAMA., 269, 2217-2220.

Cabalar, M., Boynukara, B., Gülhan, T. \& Ekin, H. (2001). Prevalence of Rotavirus, Escherichia coli K99 and O157:H7 in healthy dairy cattle herds in Van. Turkey. Turk J. Vet. Anim. Sci., 25, 191-196.

Caprioli, A., Morabito, S., Brugere, H. \& Oswalt, E. (2005). Enterohemorrhagic Escherichia coli emerging issues on virulence and modes of transmission. Vet. Res., 36, 289-311.

Cebiroglu, H. (1998). Investigations on presence of Enterohaemorrhagic E. coli O157:H7 in frozen hamburger and meatball. (Master's Degree Thesis). Istanbul University, The Instutute of Health Sciences.

Chapman, P.A., Siddons, C.A., Cerdon Malo, A.T. \& Harkin, M.A. (1997). A year study of Escherichia coli $\mathrm{O} 157: \mathrm{H} 7$ in cattle, sheep, pigs and poultry. Epidemiol. Infect., 119, 245-250.

Ciçek, E. (2008). The isolation of Esherichia coli O157:H7 in milk and feaces of cattle in Eagean Region and determination of their verotoxin. (Doctoral Thesis). Adnan Menderes University, Faculty of Medicine, Aydın, Turkey.
Dunn, J.R. (2003). The epidemiology of Shiga -Toxigenic Escherichia coli O157:H7 in Louisiana dairy cattle, beef cattle and white-tailed deer. (Doctoral Thesis). Luisiana State University.

Elder, R.O., Keen, J.E., Siragusa, G.R., BarkocyGallagher, G.A., Koohmaraie, M. \& Laegreid, W.W. (2000). Correlation of enterohemorrhagic Escherichia coli $\mathrm{O} 157$ prevalance in feces, hides and carcasses of beef cattle during processing. Proc. Natl. Acad. Sci., 97(7), 2999-3003.

Faith, NG., Shere, J.A., Brosch, R., Arnold, K.W., Ansay, S.E., Lee, M.S., Luchansky, J.B. \& Kapsar, C.W. (1996). Prevalence and clonal nature of Escherichia coli $0157: \mathrm{H} 7$ on dairy farms in Wisconsin. Appl. Environ. Microbiol., 62(5), 15191525 .

Flemming, S. \& Strockbine, NA. (2005). Bergey's Manuel of Systemic bacteriology. In: G.M. GARRITY (éd.). The genus Escherichia, 2nd ed. Springer, East Lansing, Michigan, 607-625.

Franzolin, M.R., Alves, R.C.B., Keller, R., Gomes, T.A.T, Beutin, K., Barreto, M.L., Milroy, C., Strina, A., Riberio, H. \& Trabusi, L.R. (2005). Prevalence of diarrheagenic Escherichia coli in children with diarrhea in Salvador, Bahia, Brazil. Mem. Inst. Oswaldo Cruz., 100(4), 359-363.

Garber, L.P., Wells, S.J., Hancock, D.D., Doyle, M.P., Tuttle, J., Shere, J.A. \& Zhao, T. (1995). Risk factors for shedding of Escherichia coli $0157: \mathrm{H7}$ in dairy calves. J. Am. Vet. Med. Assoc., 207, 4649.

Gonul, S.A. (1997). Çiğ süt ve peynir örneklerinde enterohemorajik E. coli'ye (O157:H7) rastlanma sıklığı. KÜKEM Dergisi, 20(2), 69-73.

Hancock, D.D., Beser, T.E., Rice, D.H., Ebel, E.D., Herriott, D.E. \& Carpenter, L.V. (1998). Multiple sources of Escherichia coli $\mathrm{O} 157$ in feedlots and dairy farms in the Northwestern USA. Prev. Vet. Med., 35(1), 11-19.

Heuvelink, A.E., Van den Biggelaar, F.L.A.M., de Boer de, E., Herbes, R.G., Melchers, W.J.G., Huisin'tveld, J.H. \& Monnens, L.A.H. (1998). Isolation and characterization of verocytotoxinproducing Escherichia coli $\mathrm{O} 157$ strains from Dutch cattle and sheep. J. Clin. Microbiology, 36, 878-882.

Keene, W.E., Sazie, E., Kok, J., Rice, D.H., Hancock, D.D., Balan, V.K., Zhao, T. \& Doyle, M.P. (1997). An outbreak of Escherichia coli i O157:H7 infections traced jerky made from deer meat. JAMA., 277, 1229-1231.

Kuyucuoglu, Y, Seker, E., Sareyyupoglu, B. \& Gurler, Z. (2011). Detection of enterohemolysin and intimin genes in Escherichia coli O157:H7 strains isolated from calves and cattle in Afyonkarahisar-Turkey. 
Journal of the Faculty of Veterinary Medicine, Kafkas University, 17(4), 663-666.

Lahti, E., Ruoho, I., Rantala, L., Hanninen, M.L. \& Honkannen-Buzalski, T. (2003). Longitudinal study of Escherichia coli $\mathrm{O} 157$ in a cattle finishing unit. Appl. Environ. Microbiology, 69, 554-561.

Mechie, S.C., Chapman, P.A. \& Siddons, C.A. (1997). A fifteen month study of Escherichia coli $\mathrm{O} 157: \mathrm{H} 7$ in a dairy herd. Epidemiol. Infect., 118, 17-25.

Oksuz, O., Arici, M., Kurultay, S. \& Gumus, T. (2004). Incidence of Escherichia coli $\mathrm{O} 157$ in raw milk and pickled cheese manifactured from raw milk in Turkey. Food Control, 15, 453-456.

Ozdamar, K. (1999). SPSS ile biyoistatistik., 3rd. ed., 341349. Eskisehir, Turkiye, Kaan Kitabevi.

Padhye, N. \& Doyle, M.P. (1992). Escherichia coli O157:H7 epidemiology, pathogenesis, and methods for detection in food. Food Prot., 55, 555-565.

Peacock, E., Jacob, V.W. \& Fallone, S.M. (2001). Escherichia coli O157:H7 etiology, clinical features, complications and treatment. Nephrology Nursing Journal, 28(5), 547- 557.

Richards, M.S., Corkish, J.D., Sayers, A.R., Maclaren, I.M., Evans, S.J. \& Wray, V. (1998). Studies of the presence of verocytotoxic Escherichia coli O157 in bovine feces submitted for the diagnostic purposes in England and Wales and on beef carcasses in abattoirs in the United Kingdom. Epidemiol. Infect., 120, 187- 192.

Schouten, J.M., Graat, E.A.M., Frankena, K., Van de Giessen, A.W., Van der Zwaluw, W.K. \& de Jong, M.C.M. (2005). A longitudinal study of Escherichia coli $\mathrm{O} 157$ in cattle of a Dutch dairy farm and in the farm environment. Vet. Microbiology, 107(3-4), 193-204.

Unluturk, A. \& Turantas, F. (1998). G1da Mikrobiyolojisi. İzmir, Türkiye, Mengi Tan Basımevi.

Unsal, C. (2007). Occurance E.coli O157: H7 in meat consumed in Erzurum. (Master's Degree Thesis). Ataturk University, The Istutute of Health Sciences, Erzurum, Turkey.

Wells, J.G., Shipmann, L.D., Greene, K.D., Sowers, E.G., Green, J.H, Cameron, D.N., Downes, F.P., Martin, M.L., Griffin, PM.. \& Ostroff, S.M. (1991). Isolation of Escherichia coli serotype O157:H7 and other shiga-like-toxin producing $E$. coli from dairy cattle. J. Clin. Microbiology, 29, 985-989.

Zhao, T., Doyle, MP., Shere, J. \& Garber, L. (1995). Prevalence of Enterohemorrhagic Escherichia coli O157:H7 in a survey of dairy herds. App. Environ. Microbiology, 61(4), 1290-1293.

Received date: 31.01 .2018

Accepted date: 25.06 .2018

*Corresponding author's:

Esin BİRDAL

Ministry of Food, Agriculture and Livestock, İstanbul Province Directorate, Erenkoy, İstanbul, Turkey

E-mail: esin_1981@yahoo.com 